\title{
GMR
}

\section{Genetic divergence between Mexican Opuntia accessions inferred by polymerase chain reaction-restriction fragment length polymorphism analysis}

\author{
S. Samah, E. Valadez-Moctezuma, K.S. Peláez-Luna, S. Morales-Manzano, \\ P. Meza-Carrera and R.C. Cid-Contreras \\ Laboratorio de Biología Molecular, Departamento de Fitotecnia, \\ Universidad Autónoma Chapingo, Texcoco, Mexico \\ Corresponding author: E. Valadez-Moctezuma \\ E-mail: evaladez@correo.chapingo.mx
}

Genet. Mol. Res. 15 (2): gmr.15027786

Received October 6, 2015

Accepted December 29, 2015

Published June 3, 2016

DOI http://dx.doi.org/10.4238/gmr.15027786

\begin{abstract}
Molecular methods are powerful tools in characterizing and determining relationships between plants. The aim of this study was to study genetic divergence between 103 accessions of Mexican Opuntia. To accomplish this, polymerase chain reaction (PCR)restriction fragment length polymorphism analysis of three chloroplast intergenic spacers $(a t p \mathrm{~B}-r b c \mathrm{~L}$, $\operatorname{trn} \mathrm{L}-\operatorname{trn} \mathrm{F}$, and $p s b \mathrm{~A}-\operatorname{trn} \mathrm{H})$, one chloroplast gene ( $y c f 1)$, two nuclear genes ( $p p c$ and $P h y \mathrm{C})$, and one mitochondrial gene (cox3) was conducted. The amplified products from all the samples had very similar molecular sizes, and there were only very small differences between the undigested PCR amplicons for all regions, with the exception of $p p c$. We obtained $5850 \mathrm{bp}$ from the seven regions, and 136 fragments were detected with eight enzymes, 37 of which $(27.2 \%)$ were polymorphic. We found that $40 \%$ of the fragments from the chloroplast regions were polymorphic, $9.8 \%$ of the bands detected in the nuclear genes were polymorphic, and $20 \%$ of the bands
\end{abstract}


in the mitochondrial locus were polymorphic. $\operatorname{trn} \mathrm{L}-\operatorname{trn} \mathrm{F}$ and $p s b \mathrm{~A}-\operatorname{trn} \mathrm{H}$ were the most variable regions. The Nei and Li/Dice distance was very short, and ranged from 0 to 0.12 ; indeed, 77 of the 103 genotypes had the same genetic profile. All the xoconostle accessions (acidic fruits) were grouped together without being separated from three genotypes of prickly pear (sweet fruits). We assume that the genetic divergence between prickly pears and xoconostles is very low, and question the number of Opuntia species currently considered in Mexico.

Key words: Prickly pear; Xoconostle; Genetic relationship; Nucleus; Mitochondria; Chloroplast

\section{INTRODUCTION}

The Cactaceae is a major New World plant family, and is popular in semiarid horticulture. It includes 127 genera and 1438 species and is divided into four subfamilies: Cactoideae, Opuntioideae, Pereskiodeae, and Maihuenioideae (Hunt, 2006). The latter two each comprise a single genus. Cactoideae, with seven tribes, is the largest subfamily, and Opuntioideae is the next largest; it includes two tribes, Opuntieae and Cylindropuntieae, which have ten and seven genera, respectively, and 192 species, 75 of which are placed in the largest genus, Opuntia (Hunt, 2006).

The subfamily Opuntioideae is widespread throughout the Americas, from Canada to southern Patagonia. It has traditionally been recognized as a monophyletic taxonomic entity (Griffith and Porter, 2009; Hernández-Hernández et al., 2011). It is characterized by a number of synapomorphies: 1) the presence of glochids (small and deciduous barbed spines); 2) woody funicular tissue surrounding the seed (funicular envelope); 3) large numbers of calcium oxalate monohydrate druses and monoclinic cluster crystals in the outer hypodermis of stems; and 4) polyporate pollen grains with peculiar exine structures (Hunt, 2006). Opuntioideae include Opuntia Mill. sensu lato (s.l.) and four associated genera (Cumulopuntia F. Ritter s.1., Maihueniopsis Speg. s.1., Pterocactus K. Schum., and Puna R. Kiesling s.1). Molecular phylogenetic studies have demonstrated that Opuntia s.l. is polyphyletic (Griffith and Porter, 2009). Therefore, Opuntia sensu stricto (s.s.) has been drastically reduced in size, with many segregate genera now recognized [e.g., Austrocylindropuntia Backeb., Brasiliopuntia (K. Schum.) A. Berger, Cylindropuntia (Engelm.) F. M. Knuth] (Hunt, 2006; Griffith and Porter, 2009). Opuntia s.s. (nopal and prickly pears) is the largest genus in the Opuntioideae, and may have originated as recently as $5.6( \pm 1.9)$ million years ago (Arakaki et al., 2011). There are 150 to 180 recognized species within the genus, including Nopalea (Hunt, 2006), 66-83 of which have only been reported in Mexico.

Members of Opuntia s.s. are cultivated worldwide as fruit and vegetable crops, and are increasingly used as forage and fodder for livestock in arid areas of the world, such as parts of Brazil, Mexico, western Asia, and northern and southern Africa. In Mexico, where species of Opuntia have been cultivated for at least 14,000 years (Casas and Barbera, 2002), they represent an iconic national figure, as illustrated on the country's flag. The Aztecs and other Mesoamerican civilizations used the cactus pads as a vegetable or fodder and the prickly pear as a seasonal sweet (prickly pear) or acid fruit (xoconostle). They are also considered an alternative natural medicine due to their antihypoglycemic, oxidative stress, and cancer- 
prevention effects. They also have antihyperlipidemic, anti-inflammatory, antidiuretic, hypocholesterolemic, immunostimulatory, and antiulcerogenic properties, including weightloss effects (Morales et al., 2012).

Opuntia is known for its difficult taxonomy. The continuous morphological variations in the genus, the synonyms, and the insufficient and inadequate morphological descriptors have all led to misclassifications (Labra et al., 2003; Caruso et al., 2010; Valadez-Moctezuma et al., 2015). Moreover, species limits are still poorly understood because of the high frequency of polyploid taxa. Therefore, it seems that chromosomal data are of little value for infrageneric classification (Majure et al., 2012a). Opuntia has been recorded as diploid to enneaploid (2n $=9 \mathrm{x}=99$ ), with $60.4 \%$ of reported counts pertaining to polyploidy individuals and another 13.4\% representing taxa with both diploid and polyploid cytotypes (Majure et al., 2012a). Furthermore, there is no comprehensive phylogeny of Opuntia s.s., so the limits of major clades are largely unknown. Numerous morphological and cytological studies have been conducted on large groups of taxa and species complexes (e.g., Majure et al., 2012a). Griffith and Porter (2009) included 28 species of Opuntia s.s. in their molecular phylogeny of the Opuntioideae, but were unable to resolve relationships within Opuntia s.s. using nuclear internal transcribed spacers (ITSs) and the plastid intergenic spacer trnL-F. Hernández-Hernández et al. (2011) and Bárcenas et al. (2011) studied phylogenetic relationships between South American Opuntia species, but only surveyed seven species and had no resolution between clades, respectively. The most complete phylogeny available for the subfamily Opuntioideae is that of Griffith and Porter (2009). They sampled 110 specimens using ITSs and the chloroplast $\operatorname{trn} \mathrm{L}-\operatorname{trn} \mathrm{F}$ regions. Majure et al. (2012b) studied 98 species of Opuntioideae, and sequenced the plastid intergenic spacers $a t p \mathrm{~B}-r b c \mathrm{~L}, n d h \mathrm{~F}-r p l 3, p s b \mathrm{~J}-p e t \mathrm{~A}$, and $\operatorname{tr} n \mathrm{~L}-t r n \mathrm{~F}$, the plastid genes $m a t \mathrm{~K}$ and $y c f 1$, the nuclear gene $p p c$, and ITSs to reconstruct the phylogeny of the Opuntieae tribe, including Opuntia s.s., which is a well-supported clade but includes Nopalea (Majure et al., 2012b). However, Opuntia s.s. has the signature of a clade that has undergone a rapid radiation (i.e., broad distribution, high morphological and species diversity, and low molecular marker divergence) (Helsen et al., 2011). Nevertheless, few of Mexican species were included in the molecular studies of the Opuntioideae subfamily, viz. O. ficus-indica and O. lasiacantha (Bárcenas et al., 2011); O. ficus-indica and O. megacantha (Griffith and Porter, 2009); O. ficus indica, O. megacantha, O. streptacantha, O. hyptiacantha, and O. robusta (Griffith, 2004); O. ficus-indica, O. hyptiacantha, O. lasiacantha, O. robusta, and O. streptacantha (Yesson et al., 2011); O. lasiacantha (Hernández-Hernández et al., 2011); and O. megacantha (Majure et al., 2012b). These were represented by one specimen from each species in all the studies mentioned above, except for O. ficus indica in Griffith (2004). Other Mexican Opuntia species with high agronomic and economic importance, such as $O$. xoconostle, $O$. albicarpa, $O$. matudae, $O$. undulata, and $O$. chaveña, have never been included in molecular phylogenetic studies. Furthermore, there have been no phylogenetic studies of Mexican Opuntia, and relationships between these species are still unclear. In addition, genetic divergence between xoconostles (Opuntia with acid fruits) and other Opuntia species (with sweet fruits) has not been characterized.

Knowledge of genetic variation and relationships between genotypes is an important consideration for classification, the utilization of germplasm resources, and plant breeding. Traditionally, cultivar identification has relied on morphological and agronomic characteristics of plant materials. Although there is substantial intraspecific variation in vegetative traits, particularly leaf (spine in Opuntia) and fruit characteristics, it is difficult to distinguish 
genotypes based on their external morphology alone. Furthermore, phenotypic characteristics are generally influenced by environmental factors and the growth stage of the plant. In Opuntia species, this requires a lengthy and expensive evaluation during the entire vegetative growth period (Labra et al., 2003). However, molecular markers overcome many limitations of morphologically based genetic analysis, and provide information that can help to differentiate accessions, provide classification, and determine taxonomic and phylogenetic positions. Molecular markers are classified as two types: a DNA marker system based on hybridization blotting, and another primarily based on polymerase chain reaction (PCR). The hybridization blotting system is represented by the restriction fragment length polymorphism (RFLP) technique (the first molecular marker technique reported), where the DNA polymorphism is detected through a labeled DNA probe on a Southern blot containing DNA digested by restriction endonucleases. The polymorphism is generated due to nucleotide substitutions or DNA rearrangements such as insertions, deletions, or single nucleotide polymorphisms (SNPs) (Botstein et al., 1980). DNA marker systems based on PCR have been frequently used in the last two decades, and include techniques such as random amplified polymorphic DNA (RAPD), inter-simple sequence repeats (ISSRs), amplified fragment length polymorphism (AFLP), simple sequence repeats (SSRs), diversity arrays technology, and SNPs. The PCRRFLP technique, sometimes also known as cleaved amplified polymorphic sequences, is a variant of RFLP. PCR-RFLP is performed by digesting a locus-specific PCR amplicon with one or more restriction enzymes, followed by separation of the DNA fragments on agarose or polyacrylamide gels. The method is considered an easy and advantageous tool for rapidly detecting DNA variation. The polymorphisms detected have stable genetic attributes; therefore, they can be used as molecular markers to distinguish individuals or genotypes within or between species (Lin et al., 2012).

RFLP detection in specific regions of chloroplast DNA (cpDNA) and mitochondrial DNA (mtDNA) amplified by PCR has been developed as a method for detecting variation, and is a source of original markers that are potentially useful for studies of evolution, phylogeny, and population genetics (Poczai et al., 2011). PCR-cpRFLP and PCR-mtRFLP have been used to separate two complex species of Leonurus cardiaca (L. cardiaca and L. quinquelobatus) (Marciniuk et al., 2014). PCR-cpRFLP has been used to investigate genetic diversity among apples (Khadivi-Khub et al., 2014), to analyze the genetic composition and differentiation of Prunus spinosa L. populations (Leinemann et al., 2014), as well as to fingerprint, identify, and authenticate varieties and species (Melgarejo et al., 2009; Sarin et al., 2013) in order to infer biogeographic and evolutionary relationships, origins, and the domestication history of plants (Dane and Liu, 2007).

Based on previous information, the objectives of this study were: 1) to investigate genetic relationships between 103 agronomically important accessions of Mexican Opuntia by PCR-RFLP analysis of seven loci, and 2) to estimate the genetic divergence between prickly pear and xoconostle genotypes.

\section{MATERIAL AND METHODS}

\section{Plant materials and DNA extraction}

A total of 106 accessions were analyzed in the present study. Samples of 103 Opuntia accessions were obtained from the germplasm banks of Crucen-UACh (Zacatecas) and 
Nopalera-UACh (Texcoco), Mexico. Several accessions are cultivated in different growing regions and are mainly used as fruit crops, while others are exploited as vegetable or fodder. These accessions are agronomically and economically important in Mexico, although unfortunately there is no information on their exact geographical origin. Three cacti [one sample of Cylindropuntia sp, one Pitahaya (Hylocereus undatus), and one Pitaya (Stenocereus thurberi)] were included as outgroups. Some Opuntia accessions were classified in delimited species but others had no specific assignation (S1 Table). Total genomic DNA was extracted using the CTAB protocol according to Valadez-Moctezuma et al. (2015). DNA quantification was estimated by spectrophotometry (Thermo Scientific NanoDrop ${ }^{\mathrm{TM}} 1000$, Wilmington, DE, USA), and DNA quality was determined on $1 \%$ agarose gel.

\section{PCR-RFLP analysis}

A pilot study that included nine markers [four loci from the chloroplast genome (the intergenic spacers $a t p \mathrm{~B}-r b c \mathrm{~L}, \operatorname{trn} \mathrm{L}-t r n \mathrm{~F}, p s b \mathrm{~A}-t r n \mathrm{H}$, and $p e t \mathrm{~A}-p s b \mathrm{~J}$ ) and one chloroplast gene $(y c f 1)$, two nuclear genes ( $p p c$ and $P h y \mathrm{C})$, one nuclear ITS, and one mitochondrial gene (cox3)] was conducted to evaluate the suitability of these markers for the present study. Primer information and the sizes of the PCR products are presented in Table 1.

The PCRs were conducted in a final volume of $25 \mu \mathrm{L}$ that contained nuclease-free water, $500 \mathrm{mM}$ dNTPs, $1 \mathrm{X}$ Taq buffer, $25 \mathrm{mM} \mathrm{MgCl}$, 20 pmol primers, $1.5 \mathrm{U}$ Taq DNA polymerase (Promega Corporation, WI, USA), and 100 ng template DNA. The thermo-cycling conditions (Axygen ${ }^{\circledR}$ MaxyGene ${ }^{\mathrm{TM}}$ Thermal Cycler, NY, USA) were as follows: one 4-min cycle at $94^{\circ} \mathrm{C}, 35$ cycles $\left[94^{\circ} \mathrm{C}\right.$ for $30 \mathrm{~s}$; annealing step (temperatures for each primer pair are listed in Table 1) for $30 \mathrm{~s} ; 72^{\circ} \mathrm{C}$ for $1.5 \mathrm{~min}$ ], and one final extension cycle at $72^{\circ} \mathrm{C}$ for $3 \mathrm{~min}$. The PCR products were separated on $1.2 \%$ agarose gels in $1 \mathrm{X}$ TAE buffer $(40 \mathrm{mM}$ Tris-acetate and $1 \mathrm{mM}$ EDTA, $\mathrm{pH} 8.0$ ). DNA staining was performed with $0.5 \mu \mathrm{g} / \mathrm{mL}$ ethidium bromide and photographed using a Molecular Imager ${ }^{\circledR}$ ChemiDoc $^{\mathrm{TM}}$ XRS system (Bio-Rad, Hercules, CA, USA). The PCR products were digested with AluI, AvaII, EcoRI, HaeIII, HhaI, HinfI, MboI, and Tru9I restriction enzymes, according to specifications by the manufacturers. The digested PCR products were loaded on $8 \%$ polyacrylamide gels. A GeneRuler ${ }^{\mathrm{TM}} 1-\mathrm{kb}$ DNA Ladder (Life Technologies, CA, USA) and a 100-bp DNA ladder (Promega Corporation) were used as references for molecular size. Electrophoresis was conducted at $220 \mathrm{v}$ for $1.5 \mathrm{~h}$ in $1 \mathrm{X}$ TBE buffer ( $89 \mathrm{mM}$ Tris-borate and $2 \mathrm{mM}$ EDTA, pH 8.0) using a Dual MGV-216-33 vertical electrophoresis gel system (C.B.S. Scientific Company Inc., CA, USA), and a $0.2 \%$ silver nitrate solution was used to stain the DNA fragments.

\section{Data analysis}

DNA bands from each marker-endonuclease enzyme combination were considered qualitative characteristics, and coded as absent " 0 " or present " 1 " in each accession/locus/ enzyme combination. Only consistent and reproducible DNA bands of two replicates were used for the corresponding analysis. Binary matrices were constructed, and the similarity between accessions was calculated using the Nei and Li/Dice coefficient. Dendrograms were independently constructed for each genome marker and for the combined data. The cophenetic correlation coefficient was computed for the dendrogram after the construction of a cophenetic matrix, in order to measure the goodness of fit between the original similarity matrix and the 
dendrogram, using NTSYSpc version 2.2. Bootstrap support values were obtained from 1000 replicates. The dendrograms were obtained using the FreeTree V0.9.1.5 software, and the TreeView V1.6.6 software (http://taxonomy.zoology.gla.ac.uk/rod/treeview.html) was used to display the trees.

\section{RESULTS}

The seven genomic regions studied were amplified using universal and specific primers (Table 1), and the sizes of the amplified fragments varied between 500 and $1550 \mathrm{bp}$ (Table 1 and Figure 1). A total of $5850 \mathrm{bp}$ were amplified, $3400 \mathrm{bp}$ of which were obtained from the chloroplast genome, $1700 \mathrm{bp}$ from the nucleus, and $750 \mathrm{bp}$ from the mitochondria. There was no observed change in length in the non-digested PCR products between the 103 accessions; however, the amplified fragment from $p p c$ exhibited small length variations that ranged from 550 to $600 \mathrm{bp}$. The $p s b \mathrm{~J}-p e t \mathrm{~A}$ locus was not considered in this study because more than one PCR product was obtained.

Table 1. DNA regions, polymerase chain reaction (PCR) product sizes, and associated primers used in this study.

\begin{tabular}{|c|c|c|c|c|c|}
\hline Genome & Region & Primer name & Source & Annealing temperature $\left({ }^{\circ} \mathrm{C}\right)$ & PCR product size $(b p)$ \\
\hline \multirow[t]{10}{*}{ Chloroplast } & \multirow[t]{2}{*}{ trnL-trnF } & TrnL (UAA) 5' exon & \begin{tabular}{|l|} 
Taberlet et al. (1991) \\
\end{tabular} & \multirow[t]{2}{*}{60} & \multirow[t]{2}{*}{1100} \\
\hline & & TrnF (GAA) & Taberlet et al. (1991) & & \\
\hline & \multirow[t]{2}{*}{$a t p B-r b c L$} & atpB.Op & Majure et al. (2012b) & \multirow[t]{2}{*}{65} & \multirow[t]{2}{*}{900} \\
\hline & & rbcL.Op & Majure et al. (2012b) & & \\
\hline & \multirow[t]{2}{*}{ psbJ-petA } & psbJ & \begin{tabular}{|l|} 
Shaw et al. (2005) \\
\end{tabular} & \multirow[t]{2}{*}{60} & \multirow[t]{2}{*}{-} \\
\hline & & petA.Op & Majure et al. (2012b) & & \\
\hline & \multirow[t]{2}{*}{$p s b \mathrm{~A}-t r n \mathrm{H}$} & $\operatorname{trnH}$ & Azuma et al. (2001) & \multirow[t]{2}{*}{62} & \multirow[t]{2}{*}{500} \\
\hline & & psbA & Sang et al. (1997) & & \\
\hline & \multirow[t]{2}{*}{$y c f 1$} & ycf1.Op118F & Majure et al. (2012b) & \multirow[t]{2}{*}{65} & \multirow[t]{2}{*}{900} \\
\hline & & ycf1.Op1330R & Majure et al. (2012b) & & \\
\hline \multirow[t]{6}{*}{ Nucleus } & \multirow[t]{2}{*}{ nrITS } & ITS4 & \begin{tabular}{|l|} 
White et al. (1990) \\
\end{tabular} & \multirow[t]{2}{*}{58} & \multirow[t]{2}{*}{700} \\
\hline & & ITS5 & \begin{tabular}{|l|} 
White et al. (1990) \\
\end{tabular} & & \\
\hline & \multirow[t]{2}{*}{$p p c$} & ppc.Op.19F & Majure et al. (2012b) & \multirow[t]{2}{*}{60} & \multirow[t]{2}{*}{550} \\
\hline & & ppc.Op.569R.2 & Majure et al. (2012b) & & \\
\hline & \multirow[t]{2}{*}{ PhyC } & PhyC F & Helsen et al. (2009) & \multirow[t]{2}{*}{60} & \multirow[t]{2}{*}{1150} \\
\hline & & PhyC R & Helsen et al. (2009) & & \\
\hline \multirow{2}{*}{ Mitochondria } & \multirow[t]{2}{*}{$\cos 3$} & $\cos 3 \mathrm{~F}$ & Duminil et al. (2002) & \multirow[t]{2}{*}{52} & \multirow[t]{2}{*}{750} \\
\hline & & $\operatorname{cox} 3 \mathrm{R}$ & Duminil et al. (2002) & & \\
\hline
\end{tabular}

\section{PCR-RFLP and genetic diversity}

Seven pairs of primers were successfully amplified from the corresponding DNA genome regions in all the Opuntia accessions (Figure 1 and Table 2). The PCR products were digested with AluI, AvaII, EcoRI, HaeIII, HhaI, HinfI, MboI, and Tru9I restriction endonucleases that have different recognition sites; four enzymes of which (EcoRI, HhaI, HinfI, and Tru9I) had restriction sites in the $a t p \mathrm{~B}-r b c \mathrm{~L}$ locus; five (AluI, HhaI, HinfI, MboI, and Tru9I) had restriction sites in the trnL-trnF region; five (AluI, HaeIII, HhaI, HinfI, and $M b o \mathrm{I}$ ) had restriction sites in the $p s b \mathrm{~A}-t r n \mathrm{H}$ region; five (AluI, HaeIII, HinfI, MboI, and Tru9I) had restriction sites in the $y c f 1$ locus; seven (AluI, AvaII, HaeIII, HhaI, HinfI, MboI, and Tru9I) had restriction sites in the ppc region; seven (AluI, AvaII, HaeIII, HhaI, HinfI, MboI, and Tru9I) had restriction sites in the PhyC locus; and four (AluI, HaeIII, HinfI, and MboI) had restriction sites in the $\operatorname{cox} 3$ region. 


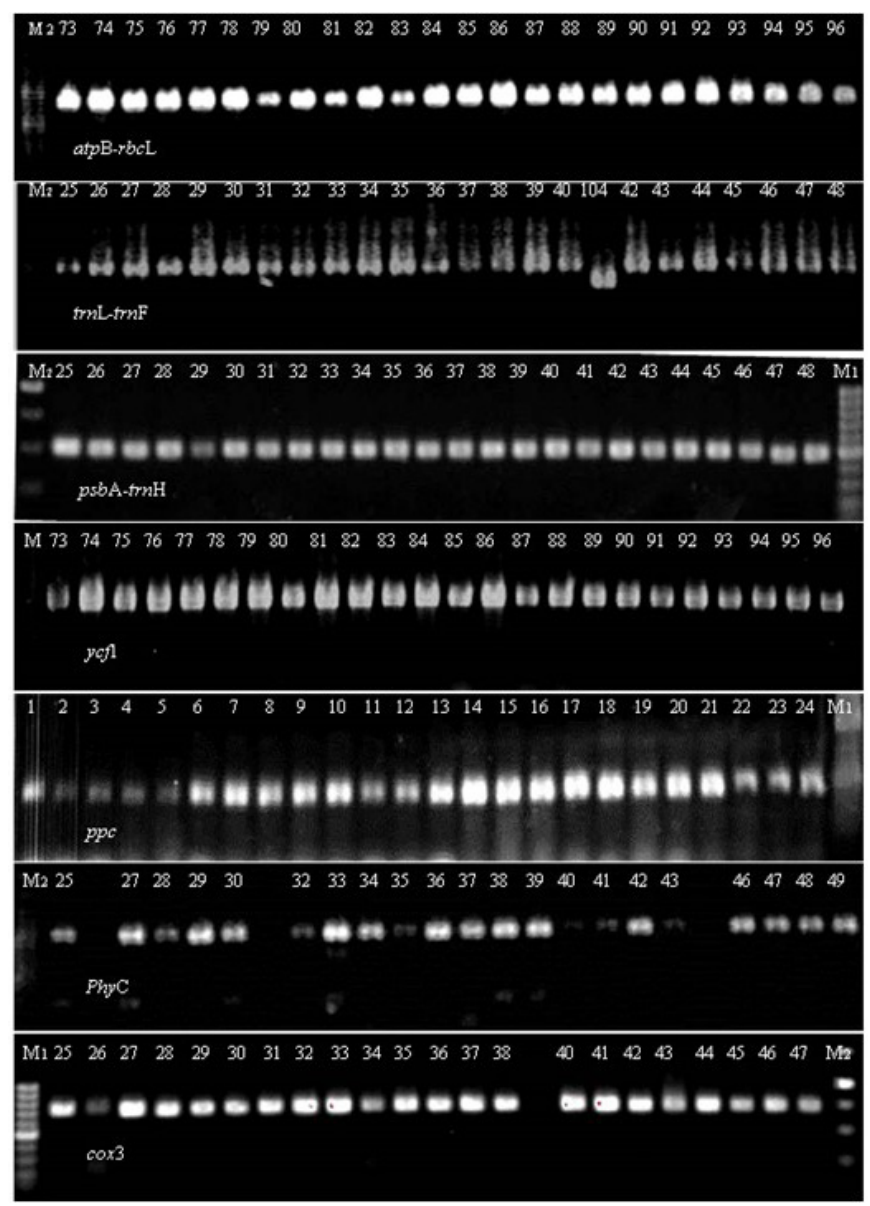

Figure 1. Representative samples of polymerase chain reaction amplifications of seven loci resolved on $1.2 \%$ agarose gels. Numbers in each lane correspond to the accessions listed in $\mathbf{S 1}$ Table. atpB-rbcL ( $900 \mathrm{bp})$, $\operatorname{trn} \mathrm{L}-\operatorname{trn} \mathrm{F}$ (1100 bp), psbA-trnH (500 bp), ycf1 (900 bp), ppc (550-600 bp), PhyC (1150), and cox3 (750 bp). Lane M1 = 100bp DNA ladder; lane $M 2=1-\mathrm{kb}$ DNA ladder.

Table 2. Digested DNA fragments of seven loci in 103 Opuntia accessions.

\begin{tabular}{|c|c|c|c|c|c|c|c|c|c|c|c|c|c|c|c|c|c|c|c|}
\hline \multicolumn{2}{|c|}{ Restriction enzyme } & \multicolumn{2}{|c|}{$A l u \mathrm{I}$} & \multicolumn{2}{|c|}{ AvaI } & \multicolumn{2}{|c|}{ EcoRI } & \multicolumn{2}{|c|}{ HaeIII } & \multicolumn{2}{|c|}{ HhaI } & \multicolumn{2}{|c|}{$\operatorname{Hinf\mathrm {I}}$} & \multicolumn{2}{|c|}{$\mathrm{MboI}$} & \multicolumn{2}{|c|}{ Tru9I } & \multicolumn{2}{|c|}{ Total } \\
\hline Genome & Locus & TF & $\mathrm{PF}$ & $\mathrm{TF}$ & PF & $\mathrm{TF}$ & $\mathrm{PF}$ & $\mathrm{TF}$ & PF & $\mathrm{TF}$ & $\mathrm{PF}$ & TF & PF & $\mathrm{TF}$ & $\mathrm{PF}$ & $\mathrm{TF}$ & $\mathrm{PF}$ & TF & $\mathrm{PF}$ \\
\hline \multirow[t]{5}{*}{ Chloroplast } & $a t p \mathrm{~B}-r b c \mathrm{~L}$ & $1 /$ & 11 & $1 /$ & 11 & 3 & 0 & $1 /$ & $/ 1$ & 2 & 0 & 6 & 0 & $/ 1$ & II & 6 & 0 & 17 & 0 \\
\hline & trnL-trnF & 2 & 2 & 11 & 11 & $1 /$ & 11 & 11 & /1 & 2 & 2 & 7 & 5 & 5 & 5 & 9 & 1 & 26 & 15 \\
\hline & $p s b \mathrm{~A}-t r n \mathrm{H}$ & 3 & 2 & $1 /$ & 11 & $1 /$ & II & 2 & 2 & 2 & 2 & 2 & 2 & 2 & 2 & $/ 1$ & $1 /$ & 12 & 10 \\
\hline & $y c f 1$ & 4 & 2 & 11 & 11 & $1 /$ & $1 /$ & 3 & 0 & $/ /$ & $/ /$ & 2 & 0 & 5 & 0 & 6 & 3 & 20 & 5 \\
\hline & \multicolumn{17}{|c|}{ Subtotal } & 75 & 30 \\
\hline \multirow[t]{3}{*}{ Nucleus } & $p p c$ & 2 & 0 & 2 & 0 & $1 /$ & 11 & 2 & 0 & 4 & 4 & 2 & 0 & 3 & 1 & 4 & 0 & 19 & 5 \\
\hline & PhyC & 3 & 0 & 2 & 0 & $1 /$ & 11 & 3 & 0 & 3 & 0 & 6 & 0 & 7 & 0 & 8 & 0 & 32 & 0 \\
\hline & \multicolumn{17}{|c|}{ Subtotal } & 51 & 5 \\
\hline Mitochondria & $\cos 3$ & 4 & 2 & 11 & 11 & $1 /$ & $1 /$ & 2 & 1 & $1 /$ & $1 /$ & 1 & 0 & 3 & 0 & $1 /$ & $1 /$ & 10 & 2 \\
\hline Total & & & & & & & & & & & & & & & & & & 136 & 37 \\
\hline
\end{tabular}

$\mathrm{TF}=$ total fragments; $\mathrm{PF}=$ polymorphic fragments; // = no restriction site for the enzyme. 
Digestion of the amplified products detected 136 fragments, 37 of which $(27.2 \%)$ were polymorphic (Table 2). A total of $40 \%$ of the fragments obtained from the chloroplast genomic regions were polymorphic $[a t p \mathrm{~B}-r b c \mathrm{~L}(0 \%), \operatorname{trn} \mathrm{L}-\operatorname{trn} \mathrm{F}(57.7 \%), p s b \mathrm{~A}-\operatorname{trn} \mathrm{H}(83.3 \%)$, and $y c f 1(25 \%)$ ], and only $9.8 \%$ of the bands in the nuclear genes [ppc (26\%) and PhyC (0\%)] were polymorphic; $20 \%$ of the fragments in the mitochondrial gene cox3 were polymorphic. The digestion products of the $a t p B-r b c \mathrm{~L}, y c f 1$, and cox3 regions in some Opuntia accessions are shown in Figures 2, 3, and 4. Similarly, Figure 5 illustrates the few polymorphisms revealed between species. The estimated genetic distance using the Nei and Li/Dice coefficient demonstrated a close relationship between the Opuntia accessions studied. In the chloroplast regions, this distance ranged between 0 and 0.13 , and in the nuclear genes, it varied from 0 to 0.04 , and from 0 to 0.11 in the mitochondrial gene. The estimated distance using all of the combined data ranged between 0 and 0.12 .

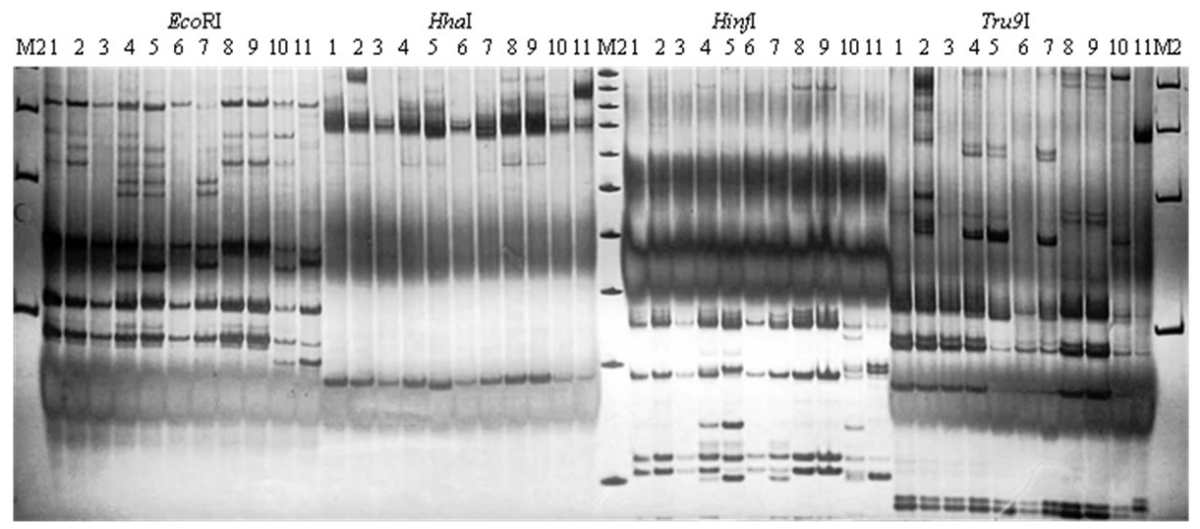

Figure 2. Digested products of the $a t p \mathrm{~B}-r b c \mathrm{~L}$ region using four enzymes (EcoRI, HhaI, HinfI, and Tru9I). Lane $1=$ Alfajayucan; lane 2 =Amarilla Jarro; lane 3 =Amarillo Aguado; lane 4=Atlixco; lane $5=$ Cylindropuntia; lane 6 $=$ Naranjo Legitimo; lane $7=$ Xoconostle Colorado; lane $8=$ Xoconostle Cuaresmero; lane $9=$ Xoconostle Blanco; lane 10 = Pitahaya; lane 11 = Pitaya; lane $M 1=100$-bp DNA ladder; lane $M 2=1-\mathrm{kb}$ DNA ladder.

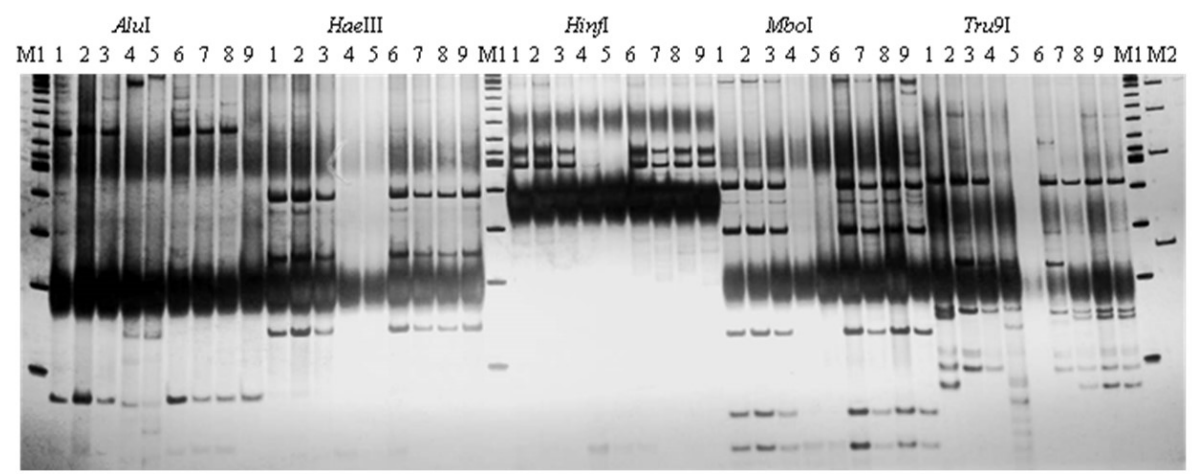

Figure 3. Digested products of the $y c f 1$ gene using five enzymes (AluI, HaeIII, HinfI, MboI, and Tru9I). Lane 1 = Cascaron; lane 2 = Copena VI; lane 3 = Cylindropuntia; lane 4 = Pitahaya; lane 5 = Pitaya; lane 6 = Tuna rosa; lane 7 = Xoconostle Colorado; lane $8=$ Xoconostle Cuaresmero; lane $9=$ Xoconostle Blanco; lane M1 = 100-bp DNA ladder; lane $M 2$ = 1-kb DNA ladder. 


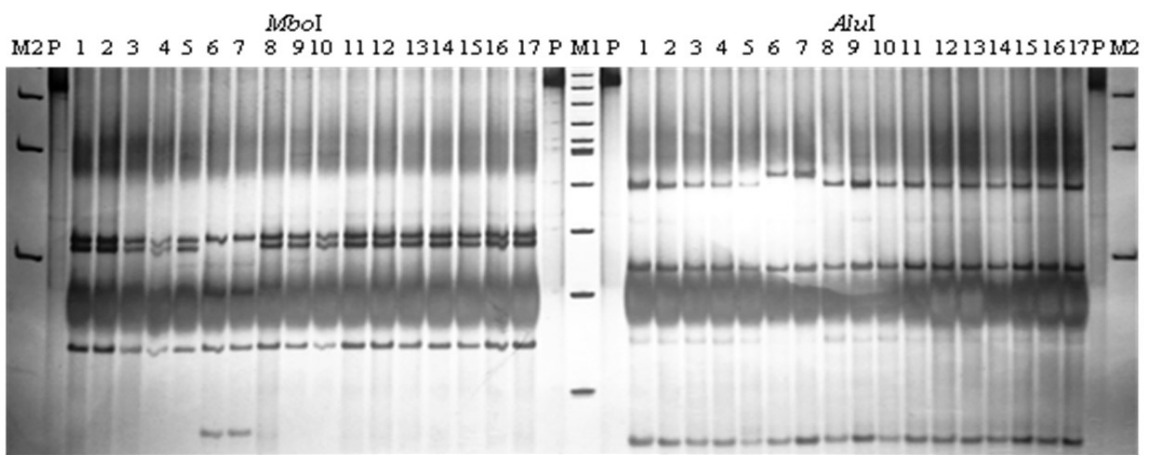

Figure 4. Digested products of the cox3 gene using two enzymes $(M b o \mathrm{I}$ and $A l u \mathrm{I})$. Lane $P=$ polymerase chain reaction product; lane $1=$ Alteña Blanco; lane 2 = Alteña Rojo; lane $3=$ Amarilla Milpa Alta; lane $4=$ Amarilla Montesa; lane 5 = Montesa; lane $6=$ Pitahaya; lane $7=$ Pitaya; lane $8=$ Reyna; lane $9=$ Toluca; lane $10=$ Plátano; lane 11 = Cardona de castilla; lane 12 =Atlixco; lane 13 = Blanco de Atlacomulco; lane $14=$ Xoconostle Colorado; lane 15 = Xoconostle Cuaresmero; lane $16=$ Xoconostle Blanco; lane 17 = Xoconostle Manzano; lane M1 = 100bp DNA ladder; lane $M 2$ = 1-kb DNA ladder.

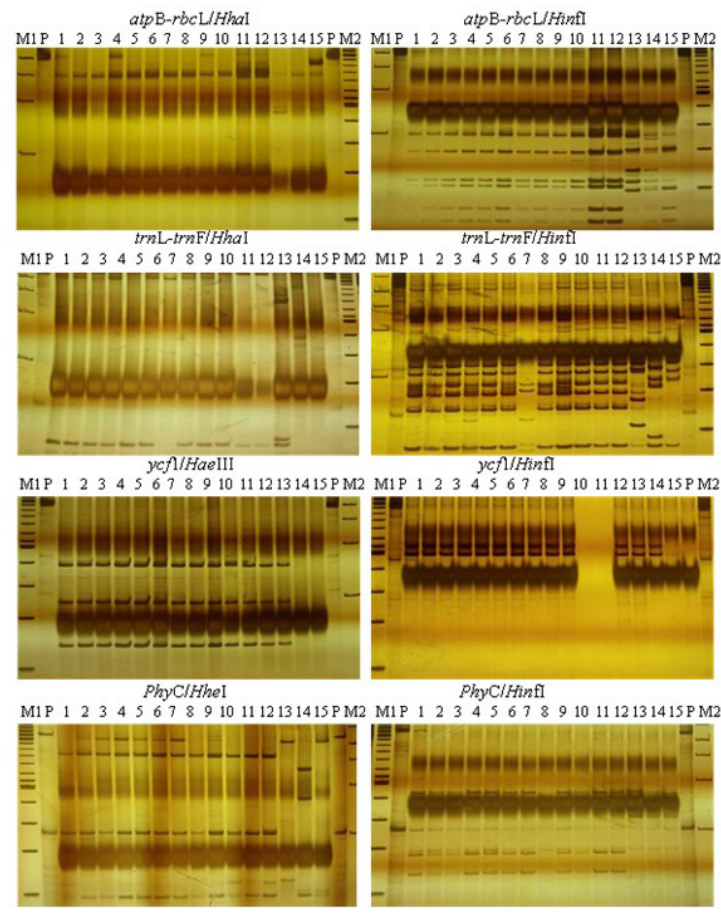

Figure 5. Amplified $(\mathrm{P})$ and digested products of primer/enzyme combinations in Opuntia accessions/species. Lane $1=$ Memelo $(O$. affinis hyptiacantha $)$; lane $2=$ Reyna $(O$. albicarpa $)$; lane $3=$ Cascarón $(O$. chaveña $)$; lane $4=$ Atlixco $(O$. ficus-indica $)$; lane $5=$ Charola Tardía $(O$. hyptiacantha $)$; lane $6=$ Sanjuanera $(O$. lasiacantha $)$; lane 7 = Pico Chulo $(O$. megacantha $)$; lane $8=$ Tapón Aguanoso $(O$. robusta $)$; lane $9=$ Cardona de Castilla $(O$. streptacantha); lane $10=$ Oreja de Elefante $(O$. undulata $)$; lane $11=$ Xoconostle Blanco $(O$. joconostle $)$; lane $12=$ Xoconostle cuaresmero (O. matudae); lane $13=$ Cylindropuntia sp; lane $14=$ Pitahaya (Hylocereus undatus); lane 15 = Pitaya (Stenocereus thurberi); lane $M 1=100-\mathrm{bp}$ DNA ladder; lane M2=1-kb DNA ladder. 


\section{Genetic relationships based on a neighbor-joining tree}

Based on the results obtained with all of the PCR-RFLP markers, a method applying a similarity matrix based on the Nei and Li/Dice coefficient was used to generate an neighborjoining (N-J) dendrogram (Figure 6). The cophenetic correlation coefficient between the original similarity matrix and the cophenetic matrix derived from the tree was large (0.998), indicating a good fit between the tree and the distance matrix. Twenty-six different genotype profiles (including the three outgroups) were obtained within the 106 accessions studied.

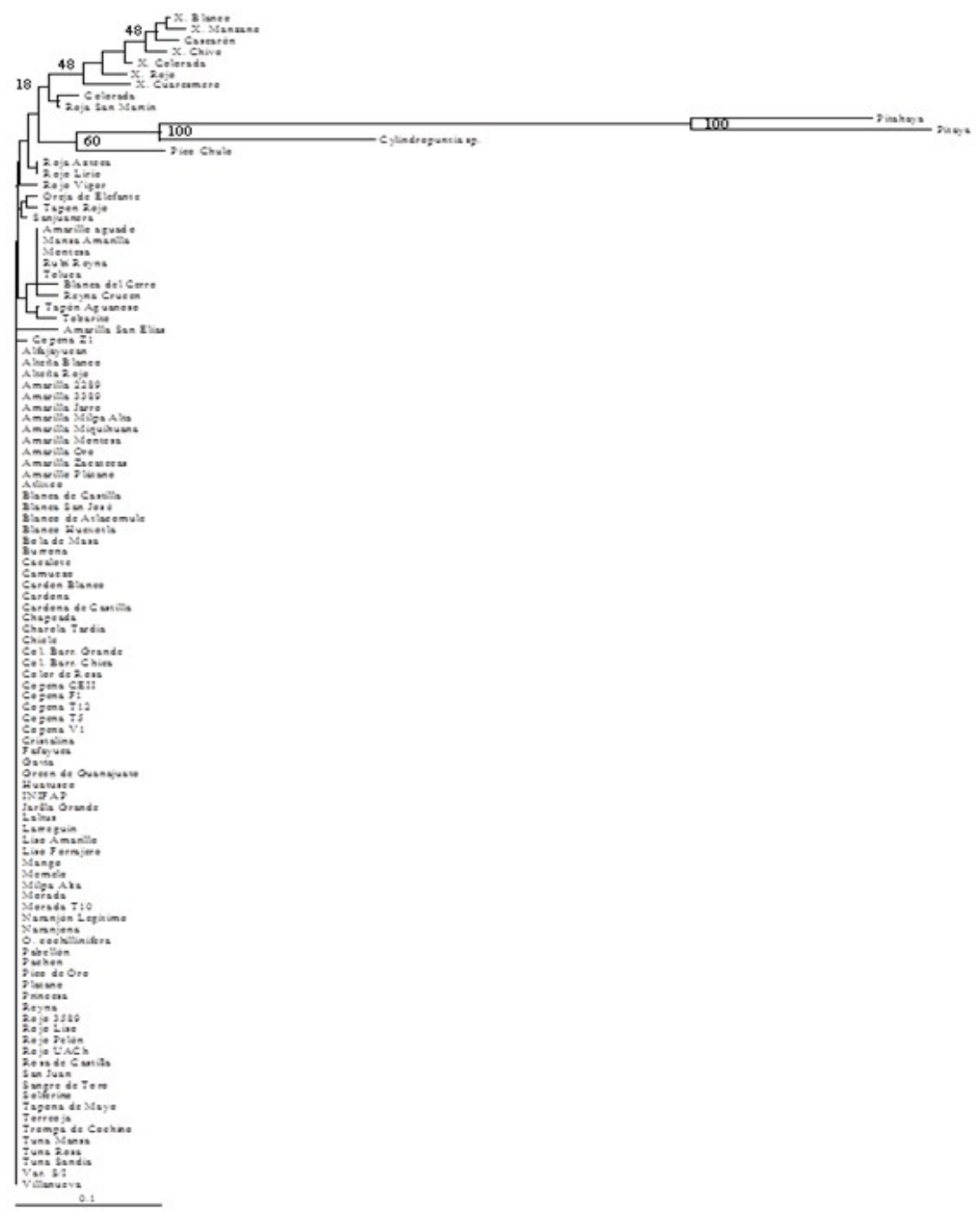

Figure 6. Genetic relationships between Mexican Opuntia. Dendrogram was constructed using the neighborjoining method with the Nei and Li/Dice coefficient. Data were resolved by polymerase chain reaction-restriction fragment length polymorphism analysis of seven regions representing the three plant genomes. Numbers at the nodes are bootstrap values as percentages of 1000 replications. 
The short genetic distance mentioned previously was reflected in the $\mathrm{N}-\mathrm{J}$ tree for the genomic regions of the chloroplast, in which 81 of the 103 genotypes had a similar genetic profile. The 'Pico Chulo' accession was the most distant. The 'Tapón Aguanoso', 'Tobarito', 'Tapón Rojo', 'Oreja de Elefante', 'Sanjuanera', 'Rojo Lirio', 'Roja Azteca', 'Reyna Crucen', 'Rojo Vigor', 'Blanca del Cerro', and 'Copena Z1' accessions were also distant. The xoconostle accessions ('Blanco', 'Colorado', 'Cuaresmero', 'Chivo', 'Manzano', and 'Rojo') were grouped with three prickly pear accessions ['San Martin', 'Cascarón', and 'Colorada' (S1 Figure A)].

The tree obtained from the N-J analysis of nuclear genes showed that 88 genotypes had the same profile. The 'Amarilla San Elias' accession was the most separate. The 'Oreja de Elefante', 'Alteña Rojo', 'Alteña Blanco', and 'X. Rojo' genotypes were slightly distanced from the others ( $\underline{\mathbf{S 1} \text { Figure B }}$ ). The dendrogram derived from the mitochondrial gene revealed two groups with 11 and 92 genotypes each. No genetic variation between the accessions within each group was found (S1 Figure $\mathbf{C})$.

The close genetic relationships within the three genomes were similar to those in the combined data; indeed, 77 of the 103 genotypes had identical genetic profiles (Figure 6). The 'Pico Chulo' accession was the most isolated from other Opuntia accessions. All of the genotypes belonging to the xoconostle group were grouped together, but did not diverge from the prickly pear accessions 'Cascarón' (with an accuracy of 48\%), 'Colorada', and 'Roja San Martin' (with an accuracy of 18\%). In addition, this grouping showed no concordance with the current taxonomic classification. It is noteworthy that the three outgroups were separated in discrete clusters from the Opuntia accessions with an accuracy of 100\% (Figure 6).

\section{DISCUSSION}

Generic limits within the genus Opuntia s.s. have historically been determined by morphological characteristics. Therefore, this study only included DNA data from PCR-RFLP analysis of seven loci that covered all three plant genomes, in order to provide an independent test of morphologically determined classification. Amplification of the seven genomic regions was successful, and the presence of one band per PCR product during gel electrophoresis indicated that the appropriate primers were used. The locus $p s b \mathrm{~J}-p e t \mathrm{~A}$ was an exception, and more specific primers for Mexican Opuntia genotypes should be designed.

Plant evolutionary and systematic biologists have traditionally used ribosomal/ nuclear and organelle (cpDNA and mtDNA) DNA markers to reconstruct phylogenies at or below the genus level (Zimmer and Wen, 2012). cpDNA and mtDNA markers are considered ideal systems in phylogeny and population genetics because of their uniparental mode of inheritance and low mutation rate compared to the nuclear genome (Galtier et al., 2009; Nock et al., 2011). Dane and Liu (2007) reported that the nature of specific DNA polymorphisms detectable using PCR-RFLP is typically limited to restriction site changes and indel mutations. In this study, the few polymorphisms detected $(27.2 \%)$ were highest in the chloroplast genome $(40 \%)$ followed by the mitochondrial genome $(20 \%)$, while the nuclear genome had the lowest percentage of polymorphisms $(9.8 \%)$. Chloroplasts contain both highly conserved genes fundamental to plant life and more variable regions that are informative over broad time scales (Nock et al., 2011). However, the mitochondrial genome evolves considerably more slowly at the nucleotide sequence level than the nuclear or chloroplast genomes, although the rate of rearrangements is extraordinarily faster in plant mtDNA than in cpDNA due to the presence of 
repeated regions, which are sources of recombination within and between mtDNA genomes. PCR-based markers that are useful at low taxonomic levels are therefore difficult to obtain, due to the presence in higher plant mtDNA of introns, intergenic sequences, duplicate sequences, and sequences of plastid and nuclear origin (Galtier et al., 2009). Nuclear ribosomal RNA that encodes repeats is not always completely homogenized, and does not always track both parents' genomes in hybrids and polyploids (Zimmer and Wen, 2012).

The spacers $p s b \mathrm{~A}-\operatorname{trn} \mathrm{H}(83.3 \%)$ and $\operatorname{trn} \mathrm{L}-\operatorname{trn} \mathrm{F}(57.7 \%)$ were the most polymorphic regions, and $p p c(26 \%), y c f 1$ (25\%), and cox3 (20\%) had intermediate polymorphic percentages. Korotkova et al. (2011) suggested that spacers are the most effective, but introns still perform better than coding regions. However, it also depends on the genetic background of the plant material studied and its evolution. The $p s b \mathrm{~A}-t r n \mathrm{H}$ spacer is among the most variable plastid spacer in the genomes of a wide range of plants. However, some problems limit its use in phylogenetic studies, such as frequent indels, microsatellites, inversions, a high degree of homoplasy, and the presence of inversions in the middle of the sequence, which can lead to incorrect alignments; however, $p s b \mathrm{~A}-\operatorname{trn} \mathrm{H}$ may still be a successful marker due to its high interspecific variability (Korotkova et al., 2011). Korotkova et al. (2011) stated that the $p s b \mathrm{~A}-t r n \mathrm{H}$ spacer is the most successful individual region for operational taxonomic unit identification at the intraspecific level, and the intergenic spacer $\operatorname{trn} \mathrm{L}-\operatorname{trn} \mathrm{F}$ has been the most frequently used locus in phylogenetic studies of the Opuntioideae (Griffith and Porter, 2009; Hernández-Hernández et al., 2011; Majure et al., 2012b). ppc and $y c f 1$ have been sequenced in the Opuntieae tribe, and are moderately informative (Hernández-Hernández et al., 2011; Majure et al., 2012b). Amplification of the mitochondrial cox3 gene in Opuntia is reported here for the first time; in addition, the phytochrome $\mathrm{C}$ gene $(P h y \mathrm{C})$ was found to be invariable in all of the genotypes investigated in the present study. Phytochromes are proteins that are involved in the sensing of light cues in green plants. They are encoded by a small gene family (PhyA-PhyE) in Arabidopsis. Most species trees use phytochrome genes for lower taxonomic levels, and employ PhyA, PhyB, or PhyC markers (Zimmer and Wen, 2012). Helsen et al. (2009) found that $P h y \mathrm{C}$ was phylogenetically informative in four species of Opuntia grown in the Galapagos Islands. Similarly, the variability of $P h y \mathrm{C}$ markers was high within an ingroup of cacti of the tribe Tephrocacteae (Opuntioideae) (Ritz et al., 2012). However, we found no variability in the sequence of this gene in the Mexican Opuntia species studied here. Majure et al. (2012b) identified 20 informative characteristics in an 861-bp fragment of the atpB-rbcL region in Opuntia species, but we did not find any polymorphisms in this region with any of the eight enzymes used, suggesting that Mexican accessions conserve the same sequence in this region. It is noteworthy that we also conducted the PCR-RFLP analysis for the ITS region in 70 genotypes and digested with four restriction enzymes (EcoRI, HaeIII, HhaI, and HinfI); however, no polymorphisms were detected among these accessions either (data not shown).

Genetic relationships between the Opuntia accessions were visualized in trees derived using the N-J method (Figure 6 and $\underline{\mathbf{S 1} \text { Figure } \mathbf{A}}, \underline{\mathbf{B}}$, and $\underline{\mathbf{C}}$ ). The cophenetic correlation coefficient was very large (0.998), indicating a consistent dendrogram. In addition, the three outgroups were separated from the Opuntia accessions with 100\% accuracy, confirming high divergence between these cactus taxa. These results were expected, because Cylindropuntia is phylogenetically closer to Opuntia than to Pitahaya or Pitaya. Overall, three quarters of the genotypes studied did not exhibit differences in the profiles of the seven loci digested with eight endonuclease enzymes. This reflects the low genetic divergence between the accessions of Mexican Opuntia studied here, although they differ morphologically and have been assigned 
to more than 13 taxonomic species (S1 Table). Helsen et al. (2009) indicated that Opuntia species in the Galápagos Islands differ morphologically but not genetically. This discrepancy may be due to the existence of a small set of unsampled loci that determine morphology, or to the fact that adaptive radiation, a process attributed to these cacti, is characterized by rapid phenotypic evolution with comparatively little genetic variation (Helsen et al., 2011). Many plant species have evolved by adaptive radiations or explosive patterns of speciation, and have evolutionary histories of only a few million years. Arakaki et al. (2011) suggested that many of the major radiations within the Cactaceae were initiated at the end of the Miocene (ca. 10-5 mya). These very short evolutionary histories result in low sequence divergence. In addition, the production of allopolyploid species in Opuntia has led to the origin of new species (Pinkava, 2002). However, these new genomic combinations often result in morphologically distinct entities, which may propagate themselves indefinitely via agamospermy, vegetatively, or by apomixis to conserve the new phenotypes. Phenotypic differences could also be due to somatic mutations; traditional cultivars have been vegetatively propagated, and could have accumulated somatic mutations with the accompanying phenotypic consequences in crop morphology and agronomic performance. Similarly, epigenetic molecular phenomena are capable of altering the temporal, spatial, and abundance patterns of gene expression. These modifications may have morphological, physiological, and ecological consequences, and are heritable across generations (Kooke et al., 2015). The study of natural epigenetic variation is complicated due to the large contribution of DNA sequence variation compared to phenotypic variation within species. Nevertheless, the absence of Opuntia genome sequencing complicates this type of study. Therefore, caution must be exercised when evaluating only morphological or only genetic data (Helsen et al., 2009).

The clustering of the accessions was not in accordance with the current assignment of genotypes in their respective species, probably because of the high phenotypic plasticity and ploidy levels and the morphological diversity of these accessions (Valadez-Moctezuma et al., 2015). For these reasons, many studies have suggested revising the classification of the Opuntia genus (Helsen et al., 2009; Caruso et al., 2010; Valadez-Moctezuma et al., 2015). It should be noted that many of the genotypes considered in this study have not yet been taxonomically assigned; however, several hypotheses can be proposed for the non-divergent accessions identified here. Firstly, the genomic regions used to differentiate accessions of Mexican Opuntia had low efficiency. However, these same loci are efficient in separating species and genera in the subfamily Opuntioideae, and in the Cactaceae family in general (Griffith and Porter, 2009; Helsen et al., 2009; Hernández-Hernández et al., 2011; Majure et al., 2012b). Another reason to discard this hypothesis is the fact that all of these genomic regions are variable at low taxonomic levels (specifically $y c f 1$ and $\operatorname{trn} \mathrm{H}-p s b \mathrm{~A}$; Dong et al., 2012). Another hypothesis is that the number of Opuntia species currently recognized is overestimating, suggesting the need to define more precisely the limits between species of this genus in Mexico. Based on cpSSR and AFLP molecular markers, Labra et al. (2003) hypothesized that $O$. ficus-indica (the most agronomically important species) should be considered a domesticated form of $O$. megacantha. However, in their study, there was no comparison with other Opuntia species. Griffith (2004), by conducting Bayesian phylogenetic analyses of nrITS DNA sequences, assumed that the taxonomic concept of $O$. ficus-indica might include clones derived from multiple lineages; therefore, it may be polyphyletic. This hypothesis seems to be supported by SSR data (Caruso et al., 2010), because O. ficusindica accessions do not cluster separately from other arborescent cactus pear species such 
as $O$. amyclaea, O. megacantha, O. streptacantha, O. fusicaulis, or O. albicarpa. ValadezMoctezuma et al. (2015), using RAPD and ISSR markers, suggested the existence of a small number of Opuntia species in Mexico with high intraspecific genetic variation. All of these data support our second hypothesis.

Other information displayed in the tree (Figure 6) is the incomplete divergence between genotypes that produce sweet fruits (prickly pears) and those that produce acid fruits (xoconostles). Separation between the two groups was poorly supported by the bootstrap value $(48 \%)$. This result was expected, because the fruit has been the organ of interest during the domestication process, and, as a result, has high morphological variability but not necessarily high genetic variability. According to Samah and Valadez-Moctezuma (2014), the absence of pulp and the presence of an edible pericarp and small seeds are the most significant morphological differences between prickly pears and xoconostles. However, no clear separation between xoconostles and prickly pears has been found using RAPD and ISSR markers (Valadez-Moctezuma et al., 2015), biochemical markers (seed storage proteins), or SSR markers (Samah et al., 2015, 2016). In addition, Espinoza Sánchez et al. (2014) did not find any tendency of separation between these two types of fruit using AFLP markers. Despite the clear morphological differences between these two types of Opuntia, these differences are not yet well defined at the DNA level.

In conclusion, genetic divergence between accessions of Mexican Opuntia was investigated by the PCR-RFLP analysis of seven regions used for molecular taxonomy. The results showed that there was little genetic divergence, despite the great morphological variability between the Mexican genotypes, and no complete separation was found between genotypes that produce sweet fruits (prickly pears) and those that produce acidic fruits (xoconostles). Therefore, the number of Opuntia species in Mexico is unclear, and methods that delimit species of this genus are urgently needed. Species delimitation will require the development of appropriate markers, or the sequencing of several genomic regions of multiple accessions from each potential species, in order to reveal intraspecific variation.

\section{Conflicts of interest}

The authors declare no conflict of interest.

\section{ACKNOWLEDGMENTS}

S. Samah received a doctorate scholarship from the Secretaría de Relaciones Exteriores, Mexico.

\section{REFERENCES}

Arakaki M, Christin PA, Nyffeler R, Lendel A, et al. (2011). Contemporaneous and recent radiations of the world's major succulent plant lineages. Proc. Natl. Acad. Sci. USA 108: 8379-8384. http://dx.doi.org/10.1073/pnas.1100628108

Azuma H, García-Franco JG, Rico-Gray V and Thien LB (2001). Molecular phylogeny of the Magnoliaceae: the biogeography of tropical and temperate disjunctions. Am. J. Bot. 88: 2275-2285. http://dx.doi.org/10.2307/3558389

Bárcenas RT, Yasson T and Hawkins JA (2011). Molecular systematics of the Cactaceae. Cladistics 27: 470-489. http:// dx.doi.org/10.1111/j.1096-0031.2011.00350.x

Botstein D, White RL, Skolnick M and Davis RW (1980). Construction of a genetic linkage map in man using restriction fragment length polymorphisms. Am. J. Hum. Genet. 32: 314-331. 
Caruso M, Currò S, Las Casas G, La Malfa S, et al. (2010). Microsatellite markers help to assess genetic diversity among O. ficus indica cultivated genotypes and their relation with related species. Plant Syst. Evol. 290: 85-97. http://dx.doi. org/10.1007/s00606-010-0351-9

Casas A and Barbera G (2002). Mesoamerican domestication and diffusion. In: Cacti: Biology and uses (Nobel PS, ed.). University of California Press, USA, 143-162.

Dane F and Liu J (2007). Diversity and origin of cultivated and citron type watermelon (Citrullus lanatus). Genet. Resour. Crop Evol. 54: 1255-1265. http://dx.doi.org/10.1007/s10722-006-9107-3

Dong W, Liu J, Yu J, Wang L, et al. (2012). Highly variable chloroplast markers for evaluating plant phylogeny at low taxonomic levels and for DNA barcoding. PLoS One 7: e35071. http://dx.doi.org/10.1371/journal.pone.0035071

Duminil J, Pemonge M-H and Petit RJ (2002). A set of 35 consensus primer pairs amplifying genes and introns of plant mitochondrial DNA. Mol. Ecol. Notes 2: 428-430. http://dx.doi.org/10.1046/j.1471-8286.2002.00263.x

Espinoza Sánchez EA, Silos Espino H, Flores Benitez S, Valera Montero LL, et al. (2014). Agrupamiento de genotipos de nopal (Opuntia spp.) de México por medio de la técnica de AFLPs y características del fruto. Fyton 83: 299-306.

Galtier N, Nabholz B, Glémin S and Hurst GDD (2009). Mitochondrial DNA as a marker of molecular diversity: a reappraisal. Mol. Ecol. 18: 4541-4550. http://dx.doi.org/10.1111/j.1365-294X.2009.04380.x

Griffith MP (2004). The origins of an important cactus crop, Opuntia ficus-indica (Cactaceae): new molecular evidence. Am. J. Bot. 91: 1915-1921. http://dx.doi.org/10.3732/ajb.91.11.1915

Griffith MP and Porter M (2009). Phylogeny of Opuntioideae (Cactaceae). Int. J. Plant Sci. 170: 107-116. http://dx.doi. org/10.1086/593048

Helsen P, Verdyck P, Tye A and Van Dongen S (2009). Low levels of genetic differentiation between O. echios varieties on Santa Cruz (Galapagos). Plant Syst. Evol. 279: 1-10. http://dx.doi.org/10.1007/s00606-008-0064-5

Helsen P, Verdyck P and Van Dongen S (2011). The influence of historical geneflow, bathymetry and distribution patterns on the population genetics of morphologically diverse Galápagos' Opuntia echios. J. Mol. Evol. 72: 315-325. http:// dx.doi.org/10.1007/s00239-011-9434-7

Hernández-Hernández T, Hernández HM, De-Nova JA, Puente R, et al. (2011). Phylogenetic relationships and evolution of growth form in Cactaceae (Caryophyllales, Eudicotyledoneae). Am. J. Bot. 98: 44-61. http://dx.doi.org/10.3732/ ajb. 1000129

Hunt DR (2006). The new cactus lexicon. dh Books, Milbourne Port, UK.

Khadivi-Khub A, Jahangirzadeh S, Ahadi E and Aliyoun S (2014). Nuclear and chloroplast DNA variability and phylogeny of Iranian apples (Malus domestica). Plant Syst. Evol. 300: 1803-1817. http://dx.doi.org/10.1007/s00606-014-1007-y

Kooke R, Johannes F, Wardenaar R, Becker F, et al. (2015). Epigenetic basis of morphological variation and phenotypic plasticity in Arabidopsis thaliana. Plant Cell 27: 337-348. http://dx.doi.org/10.1105/tpc.114.133025

Korotkova N, Borsch T, Quandt D, Taylor NP, et al. (2011). What does it take to resolve relationships and to identify species with molecular markers? An example from the epiphytic Rhipsalideae (Cactaceae). Am. J. Bot. 98: 15491572. http://dx.doi.org/10.3732/ajb.1000502

Labra M, Grassi F, Bardini M, Imazio S, et al. (2003). Relationships in Opuntia Mill. genus (Cactaceae) detected by molecular marker. Plant Sci. 165: 1129-1136. http://dx.doi.org/10.1016/S0168-9452(03)00321-2

Leinemann L, Kleinschmit J, Fussi B, Hosius B, et al. (2014). Genetic composition and differentiation of sloe (Prunus spinosa L.) populations in Germany with respect to the tracing of reproductive plant material. Plant Syst. Evol. 300 : 2115-2125. http://dx.doi.org/10.1007/s00606-014-1027-7

Lin TC, Yeh MS, Cheng YM, Lin LC, et al. (2012). Using ITS2 PCR-RFLP to generate molecular markers for authentication of Sophora flavescens Ait. J. Sci. Food Agric. 92: 892-898. http://dx.doi.org/10.1002/jsfa.4667

Majure LC, Judd WS, Soltis PS and Soltis DE (2012a). Cytogeography of the Humifusa clade of Opuntia s.s. Mill. 1754 (Cactaceae: Opuntioideae): Correlations with geographic distributions and morphological differentiation of a polyploid complex. Comp. Cytogenet. 6: 53-77. http://dx.doi.org/10.3897/compcytogen.v6i1.2523

Majure LC, Puente R, Griffith MP, Judd WS, et al. (2012b). Phylogeny of Opuntia s.s. (Cactaceae): clade delineation, geographic origins, and reticulate evolution. Am. J. Bot. 99: 847-864. http://dx.doi.org/10.3732/ajb.1100375

Marciniuk P, Gawronska B, Marciniuk J and Joachimiak AJ (2014). Taxonomic individuality of Leonurus cardiaca and Leonurus quinquelobatus in view of morphological and molecular studies. Plant Syst. Evol. 300: 255-261. http:// dx.doi.org/10.1007/s00606-013-0878-7

Melgarejo P, Martínez JJ, Hernández F, Martínez R, et al. (2009). Cultivar identification using 18S-28S rDNA intergenic spacer-RFLP in pomegranate (Punica granatum L.). Sci. Hortic. (Amsterdam) 120: 500-503. http://dx.doi. org/10.1016/j.scienta.2008.12.013

Morales P, Ramírez-Moreno E, Sanchez-Mata MC, Carvalho AM, et al. (2012). Nutritional and antioxidant properties of pulp and seeds of two xoconostle cultivars (Opuntia joconostle F.A.C. Weber ex Diguet and Opuntia matudae Scheinvar)

Genetics and Molecular Research 15 (2): gmr.15027786

(CFUNPEC-RP www.funpecrp.com.br 
of high consumption in Mexico. Food Res. Int. 46: 279-285. http://dx.doi.org/10.1016/j.foodres.2011.12.031

Nock CJ, Waters DLE, Edwards MA, Bowen SG, et al. (2011). Chloroplast genome sequences from total DNA for plant identification. Plant Biotechnol. J. 9: 328-333. http://dx.doi.org/10.1111/j.1467-7652.2010.00558.x

Pinkava DJ (2002). On the evolution of the North American Opuntioideae. In: Studies in the Opuntioideae (Cactaceae) (Hunt DR and Taylor NP, eds.). dh Books, Milbourne Port, UK, 59-98.

Poczai P, Cseh A, Taller J and Symon DE (2011). Genetic diversity and relationships in Solanum subg. Archaesolanum (Solanaceae) based on RAPD and chloroplast PCR-RFLP analyses. Plant Syst. Evol. 291: 35-47. http://dx.doi. org/10.1007/s00606-010-0371-5

Ritz CM, Reiker J, Charles G, Hoxey P, et al. (2012). Molecular phylogeny and character evolution in terete-stemmed Andean opuntias (Cactaceae-Opuntioideae). Mol. Phylogenet. Evol. 65: 668-681. http://dx.doi.org/10.1016/j. ympev.2012.07.027

Samah S and Valadez-Moctezuma E (2014). Morphological seeds descriptors for characterize and differentiate genotypes of Opuntia (Cactaceae, Opuntioideae). Annu. Res. Rev. Biol. 4: 3791-3809. http://dx.doi.org/10.9734/ $\underline{\mathrm{ARRB} / 2014 / 11606}$

Samah S, Ventura-Zapata E and Valadez Moctezuma E (2015). Fractionation and electrophoretic patterns of seed protein of Opuntia genus. A preliminary survey as a tool for accession differentiation and taxonomy. Biochem. Syst. Ecol. 58: 187-194. http://dx.doi.org/10.1016/j.bse.2014.12.005

Samah S, De Teodoro Pardo CV, Serrato Cruz MA and Valadez-Moctezuma E (2016). Genetic diversity, genotype discrimination, and population structure of Mexican Opuntia sp., determined by SSR markers. Plant Mol. Biol. Rep. 34: 146-159. http://dx.doi.org/10.1007/s11105-015-0908-4

Sang T, Crawford D and Stuessy T (1997). Chloroplast DNA phylogeny, reticulate evolution, and biogeography of Paeonia (Paeoniaceae). Am. J. Bot. 84: 1120-1136. http://dx.doi.org/10.2307/2446155

Sarin B, Clemente JPM and Mohanty A (2013). PCR-RFLP to distinguish three Phyllanthus sp., commonly used in herbal medicines. S. Afr. J. Bot. 88: 455-458. http://dx.doi.org/10.1016/j.sajb.2013.09.011

Shaw J, Lickey EB, Beck JT, Farmer SB, et al. (2005). The tortoise and the hare II: relative utility of 21 noncoding chloroplast DNA sequences for phylogenetic analysis. Am. J. Bot. 92: 142-166. http://dx.doi.org/10.3732/ajb.92.1.142

Taberlet P, Gielly L, Pautou G and Bouvet J (1991). Universal primers for amplification of three non-coding regions of chloroplast DNA. Plant Mol. Biol. 17: 1105-1109. http://dx.doi.org/10.1007/BF00037152

Valadez-Moctezuma E, Samah S and Luna-Paez A (2015). Genetic diversity of Opuntia spp. varieties assessed by classical marker tools (RAPD and ISSR). Plant Syst. Evol. 301: 737-747. http://dx.doi.org/10.1007/s00606-014-1112-y

White TJ, Bruns T, Lee S and Taylor JW (1990). Amplification and direct sequencing of fungal ribosomal RNA genes for phylogenetics. In: PCR protocols: A guide to methods and applications (Innis MA, Gelfand D, Sninsky JJ and White TJ, eds.). Academic Press, San Diego, California, USA, 315-322.

Yesson C, Bárcenas RT, Hernández HM, Ruiz-Maqueda MdeL, et al. (2011). DNA barcodes for Mexican Cactaceae, plants under pressure from wild collecting. Mol. Ecol. Resour. 11: 775-783. http://dx.doi.org/10.1111/j.17550998.2011.03009.x

Zimmer EA and Wen J (2012). Using nuclear gene data for plant phylogenetics: progress and prospects. Mol. Phylogenet. Evol. 65: 774-785. http://dx.doi.org/10.1016/j.ympev.2012.07.015

\section{Supplementary material}

S1 Table. Opuntia accessions used in this study and their corresponding species.

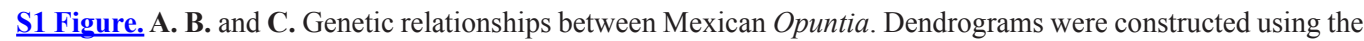
neighbor-joining method with the Nei and Li/Dice coefficient. Data were resolved by polymerase chain reactionrestriction fragment length polymorphism analysis. A. Chloroplast regions; B. mitochondrial regions; and C. the nucleus. 